ISSN 0258-7122

Bangladesh J. Agril. Res. 34(1) : 25-31, March 2009

\title{
PHENOTYPIC DIVERSITY OF COCONUT GERMPLASM CONSERVED AT DIFFERENT STATIONS OF BARI
}

\author{
MD. NAZIRUL ISLAM ${ }^{1}$, MD. AMJAD HOSSAIN ${ }^{2}$ AND MD. SHARAF UDDIN ${ }^{3}$
}

\begin{abstract}
Diversity of coconut germplasm being conserved at different Regional and Substations of the Bangladesh Agricultural Research Institute (BARI) was estimated during 2001-2002. Diversity indices $\left(\mathrm{D}^{2}\right)$ ranged from 1068.96 to 171.93 . Maximum diversity was observed between BARI Narikel-2 and Rahmatpur Yellow Dwarf. Genotypes of Regional Agricultural Research Station, Jessore and BARI Narikel-2 were found morphologically similar. Population under conservation at Jamalpur and lshwardi stations were found close to BAR! Narikel-1. Similar relationships among the genotypes were reflected when they were grouped into several clusters. Out of six clusters, the members of cluster II were homogenous, while that of cluster IV showed heterogenicity.
\end{abstract}

Key Words: Phenotypic diversity, coconut germplasm.

\section{Introduction}

Tall type cross-pollinated coconut is widely cultivated in Bangladesh (Ahmad, 1982). Due to cross-pollination and human selection, variations are noticed in coconut germplasm of Bangladesh. The yield of nut is very low (21 nut/plant/year) as compared to many other coconut growing countries in the world (BBS, 2002). With a viev to improving coconut, Bangladesh Agricultural Research Institute (BARI) collected germplasm from home and abroad during early 60s (Tabibullah and Ahmed, 1976). After a long and systematic evaluation, BARI recommended two of them fbr cultivation throughout the country in 1996 (BARI, 2000). However, the amount and extent of diversity within the collection are not yet known. Characterization, documentation, and evaluation of germplasm are essential for initiating any programme on development of coconut. Hence, the study was undertaken to estimate phenotypic diversity of the conserved coconut germplasm of BARI.

\section{Materials and Method}

The study was conducted on 9 populations at 6 Research Stations of BARI during 2001 -2002. The populations were named according to the conservation sites. Data on stem, leaf, flowers, fruit (whole nut and dehusked nut, liquid endosperm), solid endosperm (kernel) were recorded from 30 sampled palts followed by IPGRI

\footnotetext{
${ }^{1 \& 2}$ Senior Scientific Officer (Hort), RARS, Jessore, ${ }^{3}$ Scientific Officer, HRC, RARS, Rahamtpur, Barisal, Bangladesh.
} 
(1996) manual. The collected data were summarized and subjected to diversity analysis by SAS 6.12 and SPSS-9.5 computer packages. Principal component analysis (PCA) and clustering were carried to assess the pattern of morphological variation. To assess cohesiveness of the population, a dendrogram of the populations was developed (Fig. 1). Locations of the populations with cultivar names are presented in Table 1.

Table 1. Coconut germplasm conserved at different stations of BARI.

\begin{tabular}{|c|c|c|c|c|}
\hline $\begin{array}{l}\text { Population } \\
\text { name }\end{array}$ & $\begin{array}{c}\text { Other /ethnic } \\
\text { name }\end{array}$ & $\begin{array}{c}\text { Population } \\
\text { size (no.) }\end{array}$ & Location & $\begin{array}{c}\text { Year of } \\
\text { plantation }\end{array}$ \\
\hline $\begin{array}{l}\text { BAR1 } \\
\text { Narikel-1 }\end{array}$ & Deshi Narikel & 400 & $\begin{array}{l}\text { RARS, Rahmatpur } \\
\text { Barisal }\end{array}$ & 1965 \\
\hline $\begin{array}{l}\text { BARI } \\
\text { Narikel-2 }\end{array}$ & Malayan Tall & 1200 & $\begin{array}{l}\text { RARS, Rahmatpur } \\
\text { Barisal }\end{array}$ & 1966 \\
\hline Rahmatpur Tall & Singhalcse Tall & 700 & $\begin{array}{l}\text { RARS, Rahmatpur } \\
\text { Barisal }\end{array}$ & 1966 \\
\hline $\begin{array}{l}\text { Rahmatpur } \\
\text { Yellow Dwarf }\end{array}$ & $\begin{array}{l}\text { Chandina/ } \\
\text { Barodagia }\end{array}$ & 200 & $\begin{array}{l}\text { RARS, Rahmatpur } \\
\text { Barisal }\end{array}$ & 1966 \\
\hline Khairtala Tall & Khairtala Tall & 300 & & 1969 \\
\hline Hathazari Tall & Hathazari Tall & 200 & ARS, Raikhali & 1967 \\
\hline Hathazari Red Tall & $\begin{array}{l}\text { Bini Narikel/ } \\
\text { Shundhi Narikel }\end{array}$ & 35 & $\begin{array}{l}\text { RARS, Rahmatpur } \\
\text { Barisal }\end{array}$ & 1967 \\
\hline JamalpurTall & Deshi Narikel & 150 & $\begin{array}{l}\text { RARS, Hathazari, } \\
\text { Chittagong }\end{array}$ & 1968 \\
\hline lshurdi Tall & Deshi Narikel & 200 & RARS, Jamalpur & 1966 \\
\hline
\end{tabular}

\section{Results and Discussion}

The estimated $\mathrm{D}^{2}$ values for all possible combinations between pairs of genotypes ranged from 171.93 (between Jamalpur Tall and Ishurdi Tall) to 1068.96 (between BARI Narikel-2 and Rahmatpur Yellow Dwarf) (Table 2). Diversity index of BARI Narikel-2 (2) ranged from 223.393 to 1068.96 with respect to other genotypes. The minimum distance between BARI Narikel-2 and Khairtala Tall (5) implies that they might be developed from the same source of planting materials. Jamalpur Tall (8) found closer to Ishurdi Tall (9) although they are located in different agro-ecological zones (AEZ). Non-corresponding distribution of germplasm to geographical locations also reported by Nadaf et al. (1986) Shewe et al. (1972) and Shunmugam et al. (1982). Similar patterns of relationship of genotypes reflected in dendrogram (Fig. 1). 


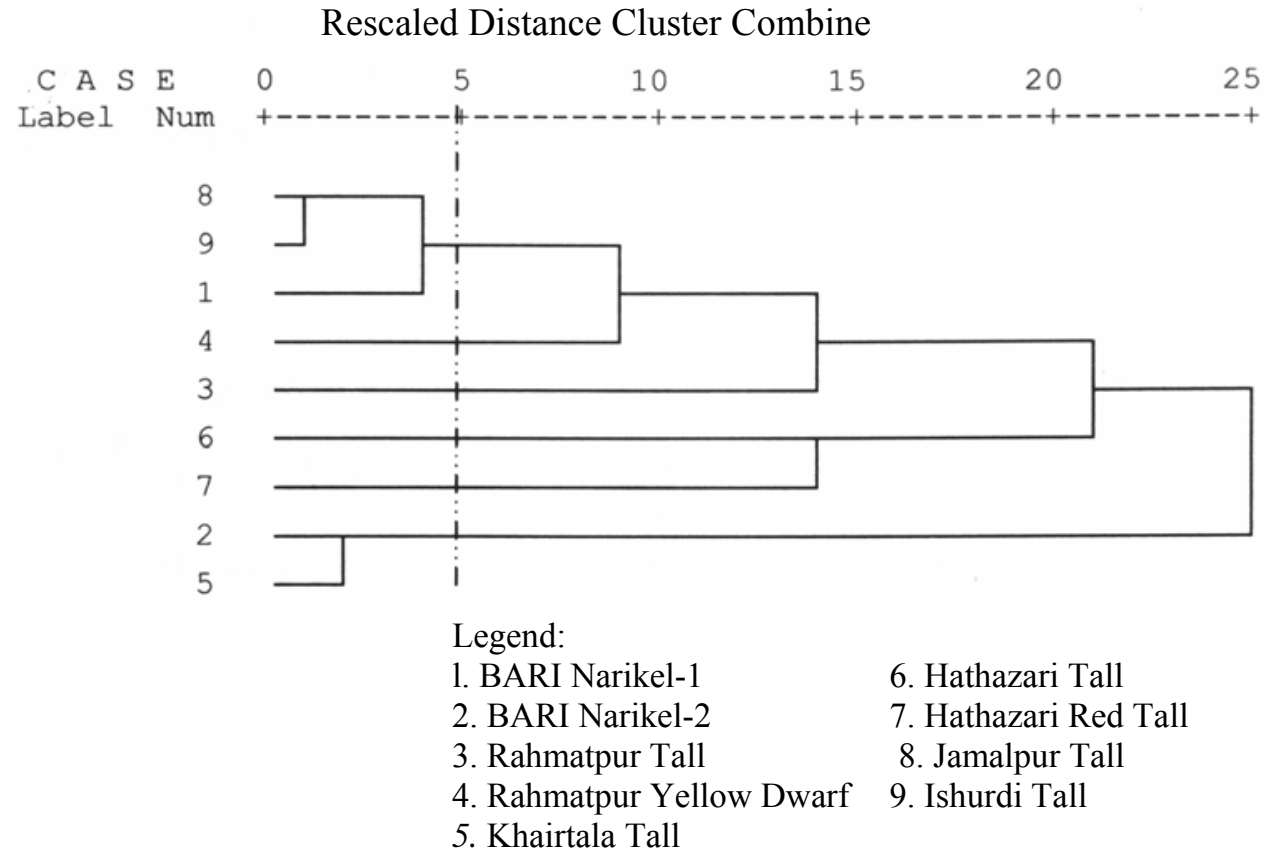

Fig. 1. Dendrogram using average linkage between the conserved genotypes at different station of BARI.

Table 2. Estimated D2 values of coconut germ plasm conserving at different BARI stations.

\begin{tabular}{|c|c|c|c|c|c|c|c|c|}
\hline Genotype & 1 & 2 & 3 & 4 & 5 & 6 & 7 & 8 \\
\hline 1 & 498.345 & 459.058 & 577.276 & 377.492 & 434.655 & $\begin{array}{l}5 \\
13.945\end{array}$ & 358.754 & 248.423 \\
\hline 2 & & 740.371 & 1068.962 & 223.393 & 555.904 & 858.377 & 829.762 & 690,929 \\
\hline 3 & & & 690.881 & 563.765 & 744.861 & 844.143 & 504.253 & 463.855 \\
\hline 4 & & & & 945.697 & 784.296 & 606.655 & 293.842 & 432.120 \\
\hline 5 & & & & & 555.241 & 763.925 & 704.013 & 571.655 \\
\hline 6 & & & & & & 539.509 & 661.339 & 576.608 \\
\hline 7 & & & & & & & 606.767 & 592.646 \\
\hline 8 & & & & & & & & 171.929 \\
\hline 9 & & & & & & & & \\
\hline
\end{tabular}

First three principal components accounted for $71 \%$ of the total diversity (Table 3). According to PCA, ten variables were selected for cluster analysis as they significantly contributed to the total diversity (Table 4). The populations were grouped into six clusters at 1-5 scale of dendrogram (Table 5). In cluster II the characters having the highest intra-cluster means were fruit weight, nut 
weight and liquid endosperm weight. In cluster III, husk weight was the higher contributing character to divergence. Meat weight and endosperm thickness had the maximum intra-cluster means in cluster V. Number of spikelets with female flower as well as number of female flowers, shell weight, nut weight without liquid endosperm and total soluble solids (TSS) of kernel in cluster VI was found maximum (Table 6). So, the characters of the clusters are important for selecting parents of hybridization programme and also recommending as varieties for cultivation (Jagadev and Samal, 1991).

Table 3. Eigenvalues of Covariance Matrix of 10 principal components for quantitative characters of conserved coconut genotypes of BARI.

\begin{tabular}{llllll}
\hline \multicolumn{1}{c}{ Component } & \multicolumn{1}{c|}{ Eigenvalue } & \multicolumn{1}{c}{ Difference } & Proportion & Cumulative \\
\hline PRIN1 & 5.221 & 0.773 & 29.008 & 29.008 \\
PRIN2 & 4.448 & 1.25 & 24.713 & 53.721 \\
PRIN3 & 3.198 & 0.491 & 17.765 & 71.486 \\
PRIN4 & 2.707 & 1.266 & 15.037 & 86.523 \\
PRIN5 & 1.441 & 0.863 & 8.006 & 94.528 \\
PRIN6 & 578 & 0.21 & 3.212 & 97.740 \\
PRIN 7 & 368 & 0.329 & 2.046 & 99.786 \\
PRIN8 & 039 & .039 & 214 & 100.000 \\
\hline
\end{tabular}

Table 4. Eigenvectors of 17 characters in first nine principal components.

\begin{tabular}{|c|c|c|c|c|c|}
\hline \multirow[t]{2}{*}{ Characters } & \multicolumn{5}{|c|}{ Component } \\
\hline & 1 & 2 & 3 & 4 & 5 \\
\hline Bole at trunk $(\mathrm{cm})$ & .514 & .154 & -.618 & .480 & .245 \\
\hline Bole at girth $(\mathrm{cm})$ & .762 & .241 & -.091 & .452 & .292 \\
\hline Length of 11 internodes $(\mathrm{cm})$ & .070 & .755 & .488 & -.012 & .397 \\
\hline No. of leaf-let & .415 & .304 & .102 & -.781 & .288 \\
\hline Length of inflorescence stalk $(\mathrm{cm})$ & -.551 & .567 & -.518 & .064 & -.315 \\
\hline No. of spike-let with $\delta$ flower & -.207 & .458 & .825 & .183 & .045 \\
\hline No. of spike-let w/o $q$ flower & -.161 & .582 & .284 & .542 & -.454 \\
\hline Total no. of spike-lets & -.164 & .578 & .701 & .331 & -.109 \\
\hline No. of female flowers & .366 & .516 & .039 & -.764 & .028 \\
\hline Fruit wt $(\mathrm{g})$ & .399 & .730 & -.466 & -.193 & -.070 \\
\hline Husk wt (g) & -.296 & .578 & -.465 & -.262 & .207 \\
\hline Nut wt (g) & 728 & .497 & -.232 & .064 & -.366 \\
\hline Shell wt (g) & .928 & .094 & .211 & -.029 & -.237 \\
\hline Liquid endosperm wt & -.187 & .890 & -.106 & .008 & -.094 \\
\hline kernel wt(g) & .201 & .118 & -.326 & .722 & .512 \\
\hline Endosperm thickness $(\mathrm{cm})$ & .776 & -.042 & .567 & .016 & .228 \\
\hline TSS of meat $(\%)$ & .736 & -.551 & .184 & -.008 & -.248 \\
\hline
\end{tabular}

(Bold figures indicate highest loading of each character under different components)

The inter-cluster distances found greater than intra-cluster distances (Table 7). Highest intra-clustcr distances were measured in cluster IV and it was lowest in cluster II. So, the results indicated that BARI Narikcl-2 and Khairtala Tall of 
cluster II were identical. On the other hand, Yellow Dwarf might contribute maximum intra -cluster diversity in IV. It can be stated here that dwarf coconuts might grow as high as of a Tall cultivar but many distinct vegetative and reproductive characters sustained throughout the life. Cluster V was found significantly different from all other clusters, although only one genotype included in that cluster. However, maximum diversity was measured between II \& IV (878.08). According to Tabibullah and Ahmed (1976), the member of cluster III is Sri Lankan origin.

Table 5. Coconut germplasm in different clusters.

\begin{tabular}{l|l|l|l}
\hline Cluster number & \multicolumn{1}{c}{$\begin{array}{c}\text { Genotype serial } \\
\text { number }\end{array}$} & \multicolumn{1}{c}{$\begin{array}{c}\text { Total } \\
\text { genotypes }\end{array}$} & \multicolumn{1}{c}{ Genotype } \\
\hline I & 1,9 & 2 & BARI Narikel-1, Ishurdi Tall \\
11 & 2,5 & 2 & $\begin{array}{l}\text { BARI Narikel-2, Khairtala Tall } \\
\text { (KHAT) }\end{array}$ \\
III & 3 & 1 & $\begin{array}{l}\text { Rahmatpur Tall } \\
\text { Rahmatpur Yellow Dwarf } \\
\text { (RHYD), Jamalpur Tall (JAMT) }\end{array}$ \\
IV & 4,8 & 2 & Hathazari Red Tall (HART) \\
V & 7 & 1 & Hathazari Tall (HART) \\
VI & 6 & 1 &
\end{tabular}

Table 6. Cluster means of 12 characters of BARI conserved coconut germplasm.

\begin{tabular}{lllllll|l|l}
\hline \multirow{2}{*}{ Character } & \multicolumn{7}{c}{ Cluster } \\
\cline { 2 - 7 } & \multicolumn{1}{c}{1} & \multicolumn{1}{c}{2} & \multicolumn{1}{c}{3} & 4 & \multicolumn{1}{c}{5} & 6 \\
\hline Girthatbole(cm) & 143.30 & 148.60 & 136.30 & 109.60 & 153.80 & 119.30 \\
Girth at trunk (cm) & 92.20 & 100.60 & 89.10 & 76.50 & 109.50 & 92.10 \\
Height of 11 internodes (cm) & 35.00 & 39.90 & 34.00 & 30.80 & 32.70 & 40.00 \\
No. of spikelets with female & 11.00 & 11.20 & 9.50 & 10.90 & 11.60 & 17.90 \\
flowers & & & & & & \\
No. of spikelets without & 20.20 & 24.00 & 14.70 & 17.20 & 18.10 & 17.70 \\
female flowers & 31.20 & 35.20 & 24.20 & 24.20 & 29.50 & 35.60 \\
Total spikelet & 22.00 & 24.20 & 21.10 & 16.80 & 12.00 & 32.20 \\
No of female flowers & 1432.00 & 1796.00 & 1500.50 & 1009.00 & 1192.00 & 1487.50 \\
Fruit wt. (g) & 546.50 & 651.70 & 866.00 & 388.50 & 251.50 & 420.00 \\
Husk wt. (g) & 881.00 & 1139.70 & 624.00 & 609.00 & 879.50 & 997.00 \\
Nut wt. (g) & 188.50 & 251.90 & 133.00 & 121.00 & 283.00 & 335.00 \\
Shell wt. (g) & 312.50 & 437.20 & 178.50 & 206.00 & 101.50 & 184.00 \\
Liquid endosperm wt (g) & 569.00 & 703.00 & 446.00 & 403.00 & 778.00 & 813.00 \\
Nut wt. without liquid & 349.50 & 343.00 & 309.50 & 247.50 & 495.00 & 109.65 \\
endosperm (g) & 4.00 & 4.00 & 4.00 & 4.00 & 12.00 & 11.90 \\
Meat wt. (g) & 3.90 & 4.30 & 4.50 & 4.20 & 7.10 & 7.30 \\
Endosperm thickness (cm) & & & & & & \\
Total soluble solid (\%) & & &
\end{tabular}

(Highest values with bold figure in column indicating important characters of the cluster) 
Hathazari Red Tall and Rahmatpur Tall were grouped separately in V and III, respectively. Khairtala Tall and BARI Narikel-2 were grouped in cluster V, while BARI Narikel-1 and Ishurdi Tall were grouped in I. Similarity in mary phenotypic characters of the genotypes brought them in a particular group. The observed diversities in the collections might be resulted from natural and human intervention (Foale, 1992).

Table 7. Intra (bold) and inter-cluster $\mathrm{D}^{2}$ values.

\begin{tabular}{l|c|c|l|r|r|c}
\hline \multicolumn{1}{c}{ Cluster } & I & \multicolumn{1}{c}{11} & \multicolumn{1}{c}{ III } & IV & V & VI \\
\hline 1 & 123.839 & 520.268 & 444.227 & 363.659 & 540.134 & 495.055 \\
II & & 111.200 & 648.155 & 878.080 & 804.125 & 543.689 \\
111 & & 0 & 586.104 & 843.779 & 744.484 \\
IV & & & 144.762 & 587.954 & 709.912 \\
V & & & & 0 & 539.074 \\
VI & & & & & & 0 \\
\hline
\end{tabular}

From the study, it can be concluded that substantial variation existing in coconut germplasm conserving at various stations of BARI. Khairta!a Tall and BARI Narikel-2 might be the same genotype. Ishurdi Tall and BARI Narikel-1 appeared genetically alike. Further collection of germplasm form home and abroad needed to enrich diversity for further development of coconut in Bangladesh.

\section{Acknowledgement}

The authors gratefully acknowledged the financial assistance of Cococnut Genetic Resources Network (COGENT)/ International Plant Genetic Institute (IPGRI) for conducting the study. The authors are also grateful to the scientists and technical staff of BARI who provide support during data collection from different research stations.

\section{References}

Ahmad, K. U. 1982. Gardener's Book of Production and Nutrition. Vol 1 (IS ed.). Mrs Mumtaj Kamal, Bungalow 2., Krishi Khamar Sharak Farm Gate, Dhaka-15. Bangladesh. pp. 273-275.

BARI. 2000. Krishi Projukti Hatboi (Handbook on Agro-technology), $2^{\text {nd }}$ edition, Bangladesh Agricultural Research Institute, Gazipur 1701, Bangladesh. 303304.

BBS. 2002. Statistical Year Book of Bangladesh 1998. Bangladesh Bureau of Statistical Division, Ministry of Planning and Evaluation, Government of Bangladesh. pp. 668.

Foale, M.A. 1992. Coconut Diversity-Present knowledge and future research needs. Paper of the IBPGRI Workshop on Coconut Genetic Resources, Cipanas, Indonesia. International Crop Network Series No. 8. IPGRI, Rome, Italy. 
Jagadev, P. N. and K.L. Samal. 1991. Multivariate analysis in niger (Guizoticahyssinicu cass.). Indian J. Genet. 5 1(4): 392-394.

Islam, M. N and A. K. M. Amzad Hossain. 2000. National coconut program in Bangladesh. COGENT Newsletter 4 (2): 10.

Nadaf, H. L., A. F. Habib and J. V. Gouds. 1986. Analysis of genetic divergence in bunch groundnut. J. Oliseeds Res. 3 (1): 37-45.

IPGRI. 1996. Manual on standardized techniques in coconut research. IPGRI-APO. P.O. Box 236 (JPM Post Office, 43400 Serdang, Selangor Darul Ehsan, Malaysia. P. 46.

Shanmugam A. S and S. R. S. Rangasamy. 1982. Multivariate analysis of genetic divergence in black gram. Madras Agric. J. 69(11): 701-706.

Shew, W. H., 13. R. Murthy, H. B. Singh and V. M. B. Rao. 1972. Genetic divergence in recent elite strains of soybean and groundnut. Indian J. Genet. 32: 285-298.

Tabibullah, M. and K. U. Ahmad. 1976. Performance of two exotic and typica coconut cultivars as compared with a local one. Bangladesh Hort. 4 (2): 11-I 7. 